\title{
Advancing the cause? Contributions of criteria and indicators to sustainable forest management in Canada ${ }^{1}$
}

\author{
by Peter N. Duinker²
}

\begin{abstract}
The aim of the paper is to take stock, based on my personal scholarly and practical experiences, of the progress made in Canada with criteria and indicators of sustainable forest management (C\&I-SFM). Some developmental history is reviewed, and applications at national and local levels are summarized. In my opinion, Canada's work in developing and applying C\&I-SFM has been beneficial, particularly in focussing forest-sector dialogues, in sensitizing people to the wide range of forest values, and in retrospective determinations of progress in SFM. Improvements over the next decade are needed in several areas: (a) improving data-collection programs; (b) linking C\&I-SFM more directly into forest policy development; (c) shifting from retrospective to prospective sustainability analysis; and (d) applying C\&I-SFM to nonindustrial forests such as protected areas and urban forests. The C\&I-SFM concept is sound. We have yet to tap its full potential in the pursuit of forest and forest-sector sustainability.
\end{abstract}

Key words: criteria and indicators, sustainable forest management, Canada

\section{RÉSUMÉ}

Lobjectif de cet article est de faire état, en me basant sur ma formation personnelle et mon expérience pratique, des progrès enregistrés au Canada au niveau des critères et des indicateurs de l'aménagement forestier durable (C\&I-AFD). Un rapide historique de leur développement est réalisé et les utilisations aux niveaux national et local sont résumées. À mon avis, le travail réalisé au Canada dans le développement et l'application des C\&I-AFD a été bénéfique, particulièrement en recentrant le dialogue du secteur forestier, en sensibilisant les gens à un vaste éventail de valeurs forestières et en identifiant rétrospectivement les progrès faits en matière d'AFD. Des améliorations doivent être apportées au cours de la prochaine décennie sur différents points : (a) améliorer les programmes de collectes de données; (b) relier plus étroitement les C\&I-AFD à lélaboration des politiques forestières; (c) passer de l'analyse rétrospective à la vision prospective de la durabilité, et (d) appliquer les C\&I-AFD aux forêts non industrielles comme les territoires protégés et les forêts urbaines. Le concept des C\&I-AFD est valable. Nous avons à faire en sorte d'en tirer son plein potentiel dans notre quête de durabilité des forêts et du secteur forestier.

Mots clés : critères et indicateurs, aménagement forestier durable, Canada

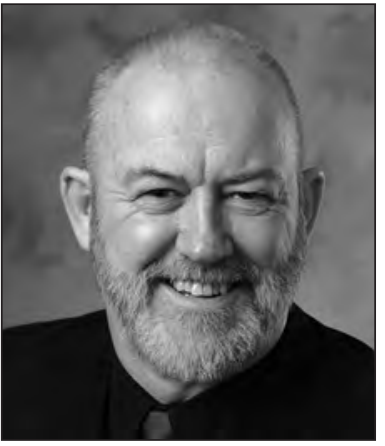

Peter N. Duinker

\section{Introduction}

Criteria and indicators (C\&I) of sustainable forest management (SFM) have become a major pre-occupation for the forest sector in Canada and abroad. Considerable amounts of time and money have been and are being spent on developing, revising, applying, re-applying, evaluating, discussing, reporting on, labouring through, and otherwise fretting over C\&I-SFM.

But what do we really know about whether the C\&I-SFM enterprise is worthwhile? What are the strengths and weaknesses of our experiences to date? My aim in this paper is to stand back from the enterprise and take stock. This is not a systematic evaluation of the utility of C\&I-SFM. Rather, it is a compilation of reflections based on almost three decades of my scholarly and practical labours on sustainability indicators. I start with a short overview of C\&I-SFM developments in Canada under the auspices of the Canadian Council of Forest Ministers (CCFM). Then I mention the application of C\&I-SFM in the Forest Futures Project of the SFM Network. Next I review three local-level applications of C\&I-SFM in Canada. Thoughts on what we do and do not do well with C\&I-SFM follow, succeeded by some concluding thoughts on improving development and application of C\&I-SFM.

\section{C\&I-SFM Developments in Canada}

Most folks knowledgeable about C\&I-SFM are aware that formal international developments began with the "International Seminar of Experts on Sustainable Development of Boreal and Temperate Forests" held in Montreal in 1993 (The Montreal Process 2005). However, Canada got started soon after the Brundtland Commission published "Our Common Future" (WCED 1987). Forestry Canada (forerunner to the

\footnotetext{
${ }^{1}$ The paper is based on a presentation by the author, with the same title, at "Session 3. Criteria and Indicators - How Useful Are They?" of the Seminar on "How Successful is Sustainable Forest Management in the UNECE Region?", a meeting of the UN Economic Commission for Europe during Regional Forest Information Week, March, Geneva.

${ }^{2}$ Professor and Director, School for Resource and Environmental Studies, Dalhousie University, 6100 University Ave., Halifax, Nova Scotia B3H 3J5. E-mail: peter.duinker@dal.ca
} 
Canadian Forest Service) started publishing its series of stateof-the-forest reports to Parliament in 1991, and the first several of these became increasingly attentive to indicators of SFM (Forestry Canada 1991, 1992, 1993). Thereafter, in parallel with early work under the banner of the Montreal Process, the CCFM started a stakeholder-engagement project to develop Canada's own set of C\&I-SFM. While highly consultative, the process was anything but systematic. From participatory experience, I recall that we never put the proposed indicators through any kind of systematic evaluation process to determine, at a first approximation and without the helpful hindsight of application experience, whether they were worthy of inclusion in the final set.

The Canadian C\&I-SFM were published in 1995 (CCFM 1995), followed soon after by a technical-readiness report (CCFM 1997) and later a data compilation (CCFM 2000). Then a revisions process began in 2001. This time it was also consultative but included an evaluation process to weed out weak indicators. Whereas the first set (CCFM 1995) included more than 80 indicators, without differentiation as to their relative importance, the second (and current) set (CCFM 2003) includes 46 indicators. Thirty-six are considered core (i.e., relatively more important) and 10 considered supporting (i.e., relatively less important if resource constraints impede proper reporting). There has been one formal data reporting to the current indicator set (CCFM 2007).

No doubt another revision of Canadian C\&I-SFM is imminent. Two studies are underway to support this. One is an investigation into the degree to which the C\&I-SFM will remain valid under a changing climate (Steenberg et al. 2011). The other is a look into how the indicators map onto the CCFM's latest national forest strategy, called a national forest vision (CCFM 2008). Both studies should bring welcome information into the revisions process. The latter should help connect the C\&I-SFM into discrete policy-development processes, something that has been lacking to date (I shall return to this theme further in the paper).

\section{National-Scale Applications}

As summarized above, the main national-scale application of the Canadian C\&I-SFM has been CCFM's reporting to Canada's citizens and policy-makers and into the Montreal Process. Also worth mentioning is the recently completed Forest Futures Project of the SFM Network. The Network had a strong 15-year run (1995-2010), near the end of which it decided to mount a scenario-based analysis of possible futures for Canada's forests and the forest sector. Unfortunately, documentation highlighting the project's results are still in production, although two papers on the scenario process have already been published (Frittaion et al. 2010, 2011).

In brief, the Forest Futures Project aimed to elevate the levels of insight that project participants would be able to bring into their respective policy discourses. Participants, numbering in the hundreds, studied and discussed the policy implications of four, substantially different scenarios for the future of Canada's forests and forest sector up to 2050. The scenarios were each structured around 24 substantive themes and 7000word essays laid out possible situations for those themes in 2050. The themes were grouped into two sets: (a) 13 drivers of change depicting major forces to which forest-sector pol- icy-makers must respond, and (b) 11 response themes depicting key elements of the forests and forest sector (see Table 1). Inspiration for the latter came directly from the study team's knowledge of Canada's C\&I-SFM. Structuring the scenarios in this way made them readily accessible to project participants who, upon reading them, would feel some comfort in understanding potential futures in terms with which they were already familiar.

Table 1. Driving forces and response themes used in scenarios of the Forest Futures Project

\begin{tabular}{|c|c|}
\hline Driving Forces & Response Themes \\
\hline 1. Global climate change & Ecological sustainability \\
\hline \multirow[t]{2}{*}{ 2. Global forest products } & 1. Biodiversity \\
\hline & $\begin{array}{l}\text { 2. Ecosystem condition and } \\
\text { productivity }\end{array}$ \\
\hline 3. Invasive species & 3. Water and soil \\
\hline 4. Geopolitics & 4. Carbon \\
\hline 5. Global energy & Social and community \\
\hline 6. Technology & sustainability \\
\hline 7. Governance & 5. Amenity values \\
\hline 8. Aboriginal empowerment & 6. Participatory processes \\
\hline 9. Air pollution & 7. Forest-related employment \\
\hline 10. Conflict over Resources & 8. Markets for forest services \\
\hline 11. Societal values & Economic sustainability \\
\hline 12. Demographics & 9. Wood harvests \\
\hline \multirow[t]{2}{*}{ 13. Industry profitability } & 10. Wood-processing Industries \\
\hline & $\begin{array}{l}\text { 11. Harvests of non-wood } \\
\text { products }\end{array}$ \\
\hline
\end{tabular}

\section{Local-Level Applications}

We may have initially conceived of C\&I-SFM for application at broad spatial levels, but exciting developments and applications have also taken place at local levels (see also Duinker 2001). Family woodlots aside, the local level of greatest meaning here is that of the forest management unit, ranging in size in Canada from a few thousand hectares up to a few million hectares. Here I highlight three local-level applications of C\&I-SFM.

\section{Model Forests}

Canada's Model Forests were established in 1992 with funding from Forestry Canada (now the Canadian Forest Service of Natural Resources Canada). As the Model Forests were getting ready to apply for continued funding under Canadas Model Forest Program for the period 1997-2002, they were all instructed to include local-level development and application of C\&I-SFM into their proposed work plans. All did so, and thus began a wave of activity across Canada to try to make sense of local-level C\&I-SFM.

The Model Forest Secretariat within the Canadian Forest Service collected all the experiences and produced a comprehensive compilation of the C\&I work accomplished across the country (von Mirbach 2000). I was fortunate to have participated in the C\&I work of several Model Forests. These experiences were indeed interesting, but as one looks back and notices that few of the Model Forests continued with the work into Phase III of the Model Forest Program (2002-2007), one wonders about the legacy of these investments. I believe they 
were of high value, mostly in terms of the learning accomplished among Model Forest partners (some Model Forests have a few dozen partners, some have hundreds). In my view, the C\&I-SFM work of the Model Forests was vital in sensitizing sector people to the full range of forest values held dear by Canadians. Moreover, it educated sector people about the need, opportunities and difficulties of keeping track of progress in SFM.

\section{Forest certification}

Canadian forest managers have access to three certification schemes-those of the Canadian Standards Association (CSA), the Forest Stewardship Council (FSC), and the Sustainable Forestry Initiative (SFI). When the CSA's Z809 SFM standard was first produced (CSA 1996), leaders of the process insisted that the standard's thematic content be structured consistent with the CCFM's new C\&I-SFM (CCFM 1995). While the criteria were used unchanged, the elements (the second level of organization in the C\&I hierarchy) were adjusted to make more sense in local-level application. The identification of indicators was left to the discretion of the certification applicant in concert with views of local stakeholders.

Z809 was revised in 2002 (CSA 2002), with continued revisions to the elements but still no mandatory indicators. That changed with the latest Z809 revision (CSA 2009) in which, due to strong recommendations of forest stakeholders across the country, the SFM Technical Committee identified 34 core mandatory indicators (see Table 2). Thus, since first adoption of Z809 in Canada in the late 1990s, forest managers using the standard have organized the sustainability chapters of their management plans according to the C\&I framework, and in the last couple of years have begun to use a consistent set of indicators. As of late 2010, some 62 million ha of timber-producing forest land in Canada are certified under Z809 (Certification Canada 2010). Before leaving certification, I should point out that while the standards of the other two standards-development organizations-FSC and SFI-have not organized their substantive content according to the CCFM C\&I-SFM, those standards still address essentially all the same substantive themes as does the CSA Z809-08 standard.

\section{Industrial forest planning}

Each province with significant amounts of Crown land used for industrial timber production specifies the way forest management plans for that land are to be prepared. For my purposes here, two provinces stand out in terms of connections to C\&I-SFM. First, the Government of Alberta (Alberta Sustainable Resource Development 2006) specified that forest management plans for Crown land would apply the planning requirements of the Z809-02 certification standard (CSA 2002). Thus, while the core indicators of the Z809-08 standard (CSA 2009) are not currently mandatory, forest managers are required to organize their local-level indicators according to the C\&I-SFM framework specified in the Z80902 document.

In response to requirements of the Class Environmental Assessment for Timber Management on Crown Lands in Ontario (Koven and Martel 1994) and the Policy Framework for Sustainable Forests (Government of Ontario 1994), the
Ontario Ministry of Natural Resources totally revamped its Forest Management Planning Manual. In the current version of the manual (Government of Ontario 2009), sustainability of forest management is to be determined in relation to objectives for a small set of sustainability indicators, as follows:

1. Social and economic objectives

- long-term harvest levels

- long-term projected available harvest area

- long-term projected available harvest volume by species group

- involvement in forest management planning

- opportunities for involvement of Aboriginal communities in plan development

- local citizens committee's self-evaluation of its effectiveness in plan development

2. Forest diversity objectives

- natural landscape patterns, forest structure and composition

- area of forest unit and development stage

- amount and distribution of old-growth forest

3. Habitats

- habitat for forest-related species, particularly species at risk

\section{What We Do Well with C\&I-SFM}

In my view, the Canadian forest sector appropriately took bold and decisive action to create its national set of C\&I-SFM. The C\&I have served us well in the following respects:

(a) The C\&I have served as a helpful common framework for sector people to organize their forest value sets. In the past two decades, I have participated in many exercises with forest sector people trying to articulate their values for use in setting directions for forest management and policy. Never (in Canada at least) have I encountered any difficulty in using the C\&I as the framework for doing this.

(b) The C\&I have really helped sensitize people, particularly forest managers, to become comprehensive and balanced in their consideration and treatment of forest values in forest management planning. The old adage that says we do not manage what we do not measure applies here-to manage for specific forest values, we must have measures associated with those values to be able to set targets and track progress. I hasten to point out, though, that this adage does not depend only on quantitative indicators. Qualitative indicators are measured using the nominal measurement scale, and nominal scales are indispensable for many forest values.

(c) Because the emphasis in C\&I programs has been on monitoring, in the sense of empirical application, the C\&I have been pivotal in tracking past degrees of satisfaction of key forest values. Using the C\&I, we have become much better at gauging actual progress in achieving sustainability. That said, the observation is relative, with much improvement yet to come.

\section{What We Do Not Yet Do Well with C\&I-SFM}

I have identified four ways in which we could make substantial improvements in our use of C\&I-SFM:

(a) We should be using our C\&I-SFM commitments to 


\subsection{Ecosystem diversity}

1.1.1 Ecosystem area by type

1.1.2 Forest area by type or species composition

1.1.3 Forest area by seral stage or age class

1.1.4 Degree of within-stand structural retention

$1.2 \quad$ Species diversity

1.2.1 Degree of habitat protection for selected focal species, including species at risk

1.2 .2

Degree of suitable habitat in the long term for selected focal species, including species at risk

Proportion of regeneration comprised of native species

Genetic diversity

1.4 Protected areas and sites of special biological and cultural significance

1.4.1 Proportion of identified sites with implemented management strategies

1.4.2 Protection of identified sacred and culturally important sites

2.1 Forest ecosystem resilience

2.1.1 Reforestation success

2.2 Forest ecosystem productivity

2.2.1 Additions and deletions to the forest area

2.2.2 Proportion of the calculated long-term sustainable harvest level that is actually harvested

3.1 Soil quality and quantity

3.1.1 Level of soil disturbance

3.1.2 Level of downed woody debris

3.2 Water quality and quantity

3.2.1 Proportion of watershed or water management areas with recent stand-replacing disturbance

4.1 Carbon uptake and storage

4.1.1 Net carbon uptake

2.1.1 Reforestation success

4.2 Forest land conversion

2.2.1 Additions and deletions to the forest area

5.1 Timber and non-timber benefits

5.1.1 Quantity and quality of timber and non-timber benefits, products, and services produced in the DFA

5.2 Communities and sustainability

5.2.1 Level of investment in initiatives that contribute to community sustainability

5.2.2 Level of investment in training and skills development

5.2.3 Level of direct and indirect employment

5.2.4 Level of Aboriginal participation in the forest economy

6.1 Aboriginal and treaty rights

6.1.1 Evidence of a good understanding of the nature of Aboriginal title and rights

6.1.2 Evidence of best efforts to obtain acceptance of management plans based on Aboriginal communities having a clear understanding of the plans

6.1.3 Level of management and/or protection of areas where culturally important practices and activities (hunting, fishing, gathering) occur

6.2 Respect for Aboriginal forest values, knowledge, and uses

6.2.1 Evidence of understanding and use of Aboriginal knowledge through the engagement of willing Aboriginal communities, using a process that identifies and manages culturally important resources and values

6.3 Forest community well-being and resilience

6.3.1 Evidence that the organization has co-operated with other forest-dependent businesses, forest users, and the local community to strengthen and diversify the local economy

6.3.2 Evidence of co-operation with DFA-related workers and their unions to improve and enhance safety standards, procedures, and outcomes in all DFA-related workplaces and affected communities

6.3.3 Evidence that a worker safety program has been implemented and is periodically reviewed and improved

6.4 Fair and effective decision-making

6.4.1 Level of participant satisfaction with the public participation process

6.4.2 Evidence of efforts to promote capacity development and meaningful participation in general

6.4.3 Evidence of efforts to promote capacity development and meaningful participation for Aboriginal communities

6.5 Information for decision-making

6.5.1 Number of people reached through educational outreach

6.5.2 Availability of summary information on issues of concern to the public 
improve data-collection programs. Two of the criteria frequently applied in evaluating proposed indicators are those of current data availability and ease of measurement. Doubtless these are important traits of a good indicator, but too often, in my view, we avoid indicators for important forest values where data are either not now collected or that would require considerable investment in monitoring systems to collect. Of course monitoring resources are limited and priorities have to be set. However, if we really are committed to SFM, and we believe strongly enough that we manage what we measure, then measurement of indicators associated with our forest values must be accomplished. Let us not abandon key proposed indicators because they fail the "cheap" test!

(b) We should be using C\&I-SFM much more intensively in processes of forest policy development. What is the point of making measurements of all kinds of important forest and forest-sector traits when nobody seems to need or ask for the data in making actual forest-policy decisions? Using the C\&I as a foundation for reporting nationally and internationally about how good (or bad) forest management is in Canada is one thing. Using C\&I to guide forest-policy development is another. Moreover, to guide forest-policy development, the C\&I need to be used in prospective analyses rather than (just) in retrospective analyses. In other words, since policy is about the choice of promising directions for the future, we need incisive glimpses into the potential future for key indicators. Peering into history is a weak guide to future possibilities. For an example, see New Brunswick Task Force on Forest Diversity and Wood Supply (2008).

(c) Associated with the foregoing discussion about using C\&I in future-oriented analyses, it is imperative also to move toward integrated consideration of the indicators rather than using them as if they were completely independent of each other. When we report nationally on data associated with the C\&I, we make little to no reference to interactions among the indicators. Perhaps when looking into the past, we do not need to. But when we aim to build internally consistent scenarios of future possibilities for the forests and forest sector, whether quantitatively using explicit forecasting tools (e.g., New Brunswick Task Force on Forest Diversity and Wood Supply 2008) or qualitatively using narrative scenarios (e.g., Frittaion et al. 2010, 2011), we cannot ignore the linkages. Indeed, we know that the entities represented by the indicators are linked in the complex real world, so we need to link them in our minds and models if we are to build credible insights into future possibilities.

(d) It would be immensely helpful if we could use the same C\&I approach to management of non-industrial forests, e.g., forested protected areas such as national parks and provincial wilderness areas, and urban forests. On the latter, we should be reminded that more than $80 \%$ of Canadians live in towns and cities, and there is growing attention to the sustainability of urban forests nationally and worldwide (Ordonez and Duinker 2010). We have made an initial attempt to use the C\&I framework, combined with the values-objectives-indicators-targets framework of the Z809-08 standard (CSA 2009), in developing the first comprehensive plan for Point Pleas- ant Park in the heart of Halifax, Nova Scotia (NIPpaysage Landscape Architects et al. 2008). In sum, I see no good reason to avoid adopting and adapting the CCFM C\&I-SFM for applications to forests beyond those that produce commercial timber.

\section{Conclusions}

Few would argue against the basic conceptual soundness of the C\&I-SFM. Their development and use have served up tremendous insights in the past two decades about forest values and how to incorporate them into forest management and policy processes. Indeed, the work, characterized by high degrees of stakeholder participation, represents the essence of the mutual learning mechanisms to be accounted for under Criterion 6 in the first set of C\&I-SFM (CCFM 1995).

In my view, the most useful applications have been those associated with local-level forest planning-these applications have been forward-looking, systems-analytical, and targeted directly at enlightening local-level forest decision-making. In relative terms, and not unduly to criticize honest and sincere attempts at gauging SFM, I see national-level reporting as less-progressive applications-they have been backward-looking, unsystematic, and poorly tied into forest policy-making.

For strong progress in advancing the SFM cause during the next decade, I suggest that we need:

(a) ubiquitous uptake for all types of forests at all spatial levels, from woodlots to continents;

(b) systems-analytical applications that link the indicators in analysis the way they are linked in nature and the economy;

(c) firm embedding in management and policy processes;

(d) resource allocations-time, personnel, and moneycommensurate to the tasks of projecting and tracking the chosen indicators; and

(e) incisive accounting for contextual change in key driving forces associated with society, the economy and the environment.

\section{Acknowledgements}

I sincerely thank staff of the UNECE (Geneva) and UNFAO (Rome) for calling upon me to develop the thoughts in this paper and for making possible my presentation at a meeting in Geneva in March 2011. I also thank James Steenberg, Diane Roddy and John Hall for reviewing the first draft.

\section{References}

Alberta Sustainable Resource Development. 2006. Alberta Forest Management Planning Standard. Edmonton, AB.

[CCFM] Canadian Council of Forest Ministers. 1995. Defining Sustainable Forest Management: A Canadian Approach to Criteria and Indicators. Ottawa, ON.

1997. Criteria and Indicators of Sustainable Forest Management: Technical Report. Ottawa, ON.

2000. Criteria and Indicators of Sustainable Forest Management in Canada: National Status 2000. Ottawa, ON. 2003. Defining Sustainable Forest Management in Canada:

Criteria and Indicators. Ottawa, ON. 2007. Criteria and Indicators of Sustainable Forest Management: Key Trends and Conditions 2005. Ottawa, ON 2008. A Vision of Canada's Forests: 2008 and Beyond. Ottawa, ON. 
Certification Canada. 2010. Certification Summary: Canada-wide, SFM, Year-end 2010 [online]. Available at www.CertificationCanada.org. [Accessed April 3, 2011].

[CSA] Canadian Standards Association. 1996. A Sustainable Forest Management System: Guidance Document. Etobicoke, ON. . 2002. CAN/CSA-Z809-02 Sustainable Forest Management. Mississauga, ON. . 2009. CAN/CSA-Z809-08 Sustainable Forest Management.

Mississauga, ON.

Duinker, P.N. 2001. Criteria and indicators of sustainable forest management in Canada: progress and problems in integrating science and politics at the local level. In A. Franc, O. Laroussinie and T. Karjalainen (eds.) Criteria and Indicators for Sustainable Forest Management at the Forest Management Unit Level. pp. 7-27. Proceedings No. 38, European Forest Institute, Joensuu, Finland.

Frittaion, C.M., P.N. Duinker, and J.L. Grant. 2010. Narratives of the future: suspending disbelief in forest-sector scenarios. Futures 42: 1156-1165. doi 10.1016/j.futures.2010.05.003.

Frittaion, C.M., P.N. Duinker, and J.L. Grant. 2011. Suspending disbelief: influencing engagement in scenarios of forest futures. Technological Forecasting and Social Change 78: 421-430.

Forestry Canada. 1991. The State of Forestry in Canada: 1990 Report to Parliament. Ottawa, ON. 80 p. . 1992. The State of Canada's Forests: Second Report to Parliament. Ottawa, ON. 85 p.

1993. The State of Canada's Forests: Third Report to Parliament. Ottawa, ON. 112 p.

Government of Ontario. 1994. Policy Framework for Sustainable Forests. Ministry of Natural Resources, Sault Ste. Marie, ON.
2009. Forest Management Planning Manual for Ontario's Crown Forests. Ministry of Natural Resources, Sault Ste. Marie, ON. Koven, A. and E. Martel. 1994. Reasons for Decision and Decision: Class Environmental Assessment by the Ministry of Natural Resources for Timber Management on Crown Lands in Ontario. Environmental Assessment Board, Toronto, ON.

New Brunswick Task Force on Forest Diversity and Wood Supply. 2008. Management Alternatives for New Brunswick's Public Forest. Government of New Brunswick, Fredericton, NB.

NIPpaysage Landscape Architects, Ekistics Planning and Design, P.N. Duinker, Black Spruce Heritage Services, Form:Media, and LandDesign Engineering Services. 2008. Point Pleasant Park Comprehensive Plan. Halifax Regional Municipality, Halifax, NS.

Ordonez, C. and P.N. Duinker. 2010. Interpreting sustainability for urban forests. Sustainability 2: 1510-1522. doi:10.3390/su2061510

Steenberg, J.W.N., P.N. Duinker, K. Zielke and L. Van Damme. 2011. Indicators of Sustainable Forest Management under a Changing Climate. Draft Report for the Canadian Council of Forest Ministers, Ottawa, ON.

The Montreal Process. 2005. The Montreal Process. Available at http://www.rinya.maff.go.jp/mpci/meetings_e.html [Accessed April 3, 2011].

von Mirbach, M. 2000. A User's Guide to Local Level Indicators of Sustainable Forest Management: Experiences from the Model Forest Network. Natural Resources Canada, Ottawa, ON.

WCED [World Commission on Environment and Development]. 1987. Our Common Future. Oxford University Press, Oxford, UK. 